\title{
4 Tapping of PGM-Ni mattes: an industry survey
}

\author{
by I. Nolet*
}

\section{Synopsis}

Matte tapping is one of the most critical operations of a matte smelter. Every smelter has developed particular matte tapping practices and tap-hole repair strategies that are often based on the experience of the smelter personnel. As a result, very little information has been published on these critical topics. This paper aims at providing the information gathered from a survey conducted in the PGM and Ni matte industries on matte tapping practices and tap-hole maintenance strategies for different PGM-Ni matte smelting operations.

Keywords matte tapping, platinum group metals, nickel, tap-hole maintenance, taphole design.

\section{Methodology}

A questionnaire was composed with key questions on each key aspect of matte tapping: tap-hole design, tap-hole operation/tapping practices, and tap-hole maintenance. The questionnaire was sent via e-mail to a large number of producers and responses were returned by e-mail. When required, clarifications were obtained to ensure the data was interpreted correctly. The responses received were compiled and summarized in tabular format, as presented in this paper.

\section{Tap-hole design}

All participating smelters (apart from Northam) use a water-cooled copper block surrounding the refractory tapping channel (Table II). The design consists of either several pieces or a single piece of copper and the style of the block depends on several aspects, such as tap-hole location (sidewall $v s$. endwall, above or below skew), wall thickness, cooling configuration in the area, etc.

\section{Table I \\ Overview of PGM and nickel matte compositions and tapping temperatures} impacts the overall smelter availability and utilization. The objective of all producers is to tap matte out of the furnace safely and reliably while minimizing downtime associated with tap-hole maintenance. This is done at various levels of sophistication in the industry, depending on factors such as the smelter matte production (i.e. furnace size), the dependency on downstream converting (on-site or offsite), smelter personnel experience, etc.

Very little information is published within the industry on matte tapping practices and tap-hole maintenance. A questionnaire was distributed to PGM and nickel matte producers regarding three key aspects of matte tapping: tap-hole design, tap-hole operation/tapping practices, and tap-hole maintenance. The responses received from these producers are summarized and presented in this paper.

\begin{tabular}{|l|c|c|}
\hline & PGM mattes & Ni mattes \\
\hline Tapping temperature $\left({ }^{\circ} \mathrm{C}\right)$ & $1180-1480$ & $1165-1200$ \\
Matte composition & & \\
Fe (wt\%) & $34-44$ & $22-36$ \\
$\mathrm{Ni}(\mathrm{wt} \%)$ & $14-19$ & $16-48$ \\
$\mathrm{Cu}(\mathrm{wt} \%)$ & $9-12$ & $1-14$ \\
$\mathrm{~S}(\mathrm{wt} \%)$ & $22-30$ & $25-30$ \\
$\mathrm{Cr}(\mathrm{wt} \%)$ & $0.1-2.5$ & - \\
Superheat $\left({ }^{\circ} \mathrm{C}\right)$ & $300-650$ & $100-520$ \\
\hline
\end{tabular}

* Hatch, South Africa.

(C) The Southern African Institute of Mining and Metallurgy, 2016. ISSN 2225-6253. This paper was first presented at the, Furnace Tapping Conference 2014, 27-28 May 2014, Misty Hills Country Hotel, Muldersdrift, South Africa. 


\section{Tapping of PGM-Ni mattes: an industry survey}

All smelters use water-cooled faceplates (Table II), which are installed external to the metal tap-blocks. They are used to retain the refractory tap-hole modules against the internal hydrostatic bath pressure. At the same time the faceplate provides a flat face for the mudgun to bear against, ensuring a good seal for closing.
All participating smelters (excluding Stillwater) use multiple bricks in their tap-holes, allowing sequential repairs and requiring deep tap-hole repairs only very infrequently. The number of tap-hole bricks varies between 4 and 10 (Figure 1), depending on the length of the tapping channel.

Table II

Matte tapping survey data for primary PGM and nickel matte smelting furnaces (Part A)

\begin{tabular}{|c|c|c|c|c|c|c|c|c|c|c|}
\hline PARAMETER & unirs & $\begin{array}{l}\text { Waterval } \\
\mathbf{F 1 . F 2}\end{array}$ & Polokwane & Mortimer & Northam & $\underset{F 1}{\text { Lonmin }}$ & Zimplats & $\begin{array}{c}\text { Stlllwater } \\
\text { EF2 }\end{array}$ & $\begin{array}{l}\text { BCL } \\
\text { Flash }\end{array}$ & Anonymous \\
\hline \multicolumn{11}{|c|}{ INFORMATION ON PLANT, TYPE OF FURNACE AND MATIE/METAL PRODUCED } \\
\hline $\begin{array}{cl}\text { Plant name } \\
\text { Pame }\end{array}$ & - & $\begin{array}{l}\text { Waterval } \\
\text { Smelter }\end{array}$ & $\begin{array}{l}\text { Polokwane } \\
\text { Metallurgical } \\
\text { Complex }\end{array}$ & Mortimer Smelter & $\begin{array}{l}\text { Northam } \\
\text { Platinum } \\
\text { Smelter }\end{array}$ & Lonmin & Zimplats & $\begin{array}{l}\text { Stillwater Mining } \\
\text { Smelter }\end{array}$ & $\mathrm{BCl}$ & - \\
\hline Plant location & & South Africa & South Africa & South Africa & South Africa & South Africa & Zimbabwe & USA & Botswana & 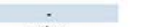 \\
\hline Type of furnace & - & electric furnace & electric furnace & electric furnace & electric furnace & electric furnace & electric furnace & electric furnace & flash furmace & other \\
\hline Furnace name & : & Furnace 1-2 & Furnace 1 & Furnace 2 & & Furnace 1 & Furnace 1 & Furnace 2 & FU 508 & \\
\hline Nature of matte/metal (primary commodity produced) & & PGM & PGM & PGM & PGM & PGM & PGM & PGM & $\mathrm{Ni}$ & Ni \\
\hline & ${ }^{\circ} \mathrm{C}$ & 1350 & 1480 & 1450 & 1350 & 1480 & $1250-1400$ & $1180-1280$ & 1200 & 1165 \\
\hline \multirow{2}{*}{\multicolumn{11}{|c|}{ Matte/metal Composition }} \\
\hline & & & & & & & & & & \\
\hline $\mathrm{Ni}$ & wes & 16 & 15 & 17 & 14.6 & 16 & $14-15$ & 19 & 16 & 48 \\
\hline cu & we\% & 9 & 9 & 10 & 9 & 10 & 9-10 & 12 & 14 & 1 \\
\hline$s$ & we\% & 30 & 30 & 29 & 24 & 30 & 22 & 29 & . & 25 \\
\hline \multicolumn{11}{|l|}{ MATTE/METAL PRODUCTION } \\
\hline Number of matte/metal tap-holes & "I & 2 & 3 & 3 & 2 & 3 & 2 & 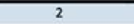 & 4 & 6 \\
\hline Number of metal/matte taps per day (from all tap-holes) & $\# / \mathrm{d}$ & 12 & 6.12 & 9 & 1 & 8 & 10 & 6 & 40 & so \\
\hline Number of ladles per tap & $"$ & 1 & 1 & 1 & 2 & 1 & 1 & 1 & 1 & 1 \\
\hline Duration of each tap & $\min$ & is & $20-35$ & 15 & 60 & 18 & $>12$ & 3 & 15 & 8.15 \\
\hline Total mass matte/metal per tap & tonnes & 15 & $28-32$ & 17 & 30 & 12 & $9-11$ & 5 & 21 & 15 \\
\hline \multicolumn{11}{|l|}{ TAPPING PRACTICES } \\
\hline Tap-hole opening practice (dorliling, Iancing or combination) & - & combination & combination & combination & lancing & combination & lancing & combination & lancing & combination \\
\hline Tap-hole closing practice (manual plugging or mud gun) & - & mud gun & mud gun & mud gun & $\begin{array}{l}\text { manual } \\
\text { plugging }\end{array}$ & mudgun & mudgun & mud gun & $\begin{array}{l}\text { manual } \\
\text { plugging }\end{array}$ & mud gun \\
\hline Total depth of tapping channel & $\mathrm{mm}$ & 1374 & 1465 & 1773 & $250^{\circ}$ & 1200 & 750 & 540 & 305 & $m 0$ \\
\hline Average drilling depth (if drilling) & $\mathrm{mm}$ & 800 & 850 & 1000 & & 900 & N/A & 640 & N/A & 350 \\
\hline Number of mudgun/drilling units on matte/metal side & $\#$ & 2 & 2 & 2 & 0 & 2 & 2 & 1 & N/A & 2 \\
\hline If lancing, is a lance guide being used for alignment purposes? & $\mathrm{Y} / \mathrm{N}$ & $\mathrm{r}$ & $r$ & 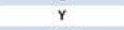 & $r$ & r & r & $\mathrm{N}$ & N & $\mathrm{N}$ \\
\hline Tap-hole Clay - Binder type & . & pitch & pitch & pitch & water & pitch & water & water & water & resin \\
\hline Tap-hole clay - Type of aggregate used (material composition) & - & alumina-based & alumina-based & alumina-based & other & alumina-based & alumina-based & other & $\begin{array}{c}\text { alumina- } \\
\text { based }\end{array}$ & alumina-based \\
\hline \multicolumn{11}{|l|}{ TAPHOLE DESIGN } \\
\hline Number of bricks in tap-hole & " & 7 & 10 & 10 & 7 & 6 & 4 & $1.540 \mathrm{~mm}$ block & 5 & 6 \\
\hline Primary refractory type used & . & alumina-based & alumina-based & magnesia-based & magnesia-based & magnesia-based & magnesia-based & alumina-based & magnesia-based & magnesia-based \\
\hline Water-cooling used & - & $\begin{array}{l}\text { Water-cooled } \\
\text { Block and } \\
\text { Faceplate }\end{array}$ & $\begin{array}{l}\text { Water-cooled Block } \\
\text { and faceplate }\end{array}$ & $\begin{array}{l}\text { Water-cooled } \\
\text { Block and } \\
\text { Faceplate }\end{array}$ & $\begin{array}{l}\text { Water-cooled } \\
\text { Faceplate Only }\end{array}$ & $\begin{array}{l}\text { Water-cooled } \\
\text { Block and } \\
\text { Faceplate }\end{array}$ & $\begin{array}{l}\text { Water-cooled } \\
\text { Block and } \\
\text { Faceplate }\end{array}$ & $\begin{array}{l}\text { Water-cooled } \\
\text { Block and } \\
\text { Faceplate }\end{array}$ & $\begin{array}{l}\text { Water-cooled } \\
\text { Block and } \\
\text { Faceplate }\end{array}$ & $\begin{array}{l}\text { Water-cooled } \\
\text { slock and } \\
\text { Faceplate }\end{array}$ \\
\hline Single block or multiple brick tapping channel design & - & $\begin{array}{l}\text { multiple brick } \\
\text { modules }\end{array}$ & $\begin{array}{l}\text { multiple brick } \\
\text { modules }\end{array}$ & $\begin{array}{l}\text { multiple brick } \\
\text { modules }\end{array}$ & $\begin{array}{l}\text { multiple brick } \\
\text { modules }\end{array}$ & $\begin{array}{l}\text { multiple brick } \\
\text { modules }\end{array}$ & $\begin{array}{l}\text { multiple brick } \\
\text { modules }\end{array}$ & single block & single block & $\begin{array}{l}\text { multiple brick } \\
\text { modules }\end{array}$ \\
\hline Use of a maintainable faceplate & $\mathrm{Y} / \mathrm{N}$ & yes & yes & yes & no & yes & yes & yes & yes & yes \\
\hline \multicolumn{11}{|l|}{ TAP-HOLE REPAIRS } \\
\hline Typical taphole life before replacement & months & 24 & 24 & 24 & N/A & $\frac{4}{4}$ & 30 & 1 & $2-4$ & 12 \\
\hline $\begin{array}{l}\text { Preventative maintenance - frequency of repair of a given } \\
\text { tap-hole }\end{array}$ & days & 14 & $25-30$ & 30 & Weekly & $\begin{array}{l}14 \text { (Alternate } \\
\text { between tap. } \\
\text { holes. } 2 \text { out of } 3 \\
\text { tap-holes are used } \\
\text { for a weee) }\end{array}$ & 3 days (for insert) & 30 & $\begin{array}{l}30 \text { days (5-brick } \\
\text { repair) }\end{array}$ & $\begin{array}{l}90 \text { taps -graphite } \\
\text { components } \\
630 \text { tapss MgCr } \\
\text { brick }\end{array}$ \\
\hline Preventative maintenance basis & - & $\begin{array}{l}\text { Number of taps } \\
\text { and tapping } \\
\text { time }\end{array}$ & number of taps & number of taps & time-based & tapping time & tapping time & number of taps & number of taps & number of taps \\
\hline
\end{tabular}

\section{Table /l (continued)}

\section{Matte tapping survey data for PGM and nickel matte slag cleaning furnaces (Part A)}

\begin{tabular}{|c|c|c|c|c|c|}
\hline PARAMETER & UNIIS & $\begin{array}{c}\text { Waterval } \\
\text { SCF }\end{array}$ & $\begin{array}{c}\text { Stillwater } \\
\mathrm{EF1} \\
\end{array}$ & $\begin{array}{l}\mathrm{BCL} \\
\text { SCF1 }\end{array}$ & $\begin{array}{l}\mathrm{BCL} \\
\text { SCF2 } \\
\end{array}$ \\
\hline \multicolumn{6}{|l|}{ INFORMATION ON PLANT, TYPE OF FURNACE AND MATIE/METAL PRODUCED } \\
\hline $\begin{array}{cl}\text { Plant name } \\
\text { Pal }\end{array}$ & - & Waterval Smelter & Stillwater Mining Smelter & $\mathrm{BCl}$ & $\mathrm{BCL}$ \\
\hline & & & & Botswana & \\
\hline Type of furnace & . & slag cleaning (electric) & slag cleaning (electric) & slag cleaning (electric) & slag cleaning (electric) \\
\hline Furnace name & . & SCF & Furnace 1 & FU 501 & FU 502 \\
\hline Nature of matte/metal (primary commodity produced) & & PGM & PGM & $\mathrm{Ni}$ & $\mathrm{Ni}$ \\
\hline Metal/matte tapping temperature & ${ }^{\circ} \mathrm{C}$ & 1250 & 1230 & 1200 & 1200 \\
\hline Estimated matte/metal liquidus temperature & ${ }^{\circ} \mathrm{c}$ & 1200 & & 1100 & 1100 \\
\hline \multicolumn{6}{|l|}{ Matte/metal Composition } \\
\hline $\mathrm{Fe}$ & wes & 35 & 39 & . & $\therefore$ \\
\hline Ni & wes & 35 & 14 & 24 & 23 \\
\hline $\mathrm{cu}_{\mathrm{s}}^{\mathrm{u}}$ & wto & 15 & 12 & 19 & 17 \\
\hline \multicolumn{6}{|l|}{ MATIE/METAL PRODUCTION } \\
\hline Number of matte/metal tap-holes & " & 2 & 2 & 2 & 2 \\
\hline Number of metal/matte taps per day (from all tap-holes) & t/d & 6 & 0.03 & 6 & 2 \\
\hline Number of ladles per tap & " & 1 & 1 & 1 & 1 \\
\hline $\begin{array}{l}\text { Duration of each tap } \\
\text {. }\end{array}$ & $\min$ & 15 & 3 & 15 & 15 \\
\hline Total mass matte/metal per tap & tonnes & 15 & 5 & 21 & 21 \\
\hline \multicolumn{6}{|l|}{ TAPPING PRACTICES } \\
\hline $\begin{array}{l}\text { Tap-hole opening practice (drilling, lancing or combination) } \\
\text { Tap-hole closing practice (manual plugsing or mud gun) }\end{array}$ & $\because$ & $\begin{array}{c}\text { combination } \\
\text { mud gun }\end{array}$ & $\begin{array}{c}\text { combination } \\
\text { mud gun }\end{array}$ & $\begin{array}{c}\text { lancing } \\
\text { manual plugging }\end{array}$ & $\begin{array}{c}\text { lancing } \\
\text { manual plugging }\end{array}$ \\
\hline Total depth of tapping channel & $\mathrm{mm}$ & 1050 & 540 & 305 & 305 \\
\hline Average drilling depth (if drilling) & mm & 800 & 640 & N/A & N/A \\
\hline Number of mudgun/drilling units on matte/metal side & $\#$ & 2 & 1 & N/A & N/A \\
\hline $\begin{array}{l}\text { If lancinge, is a lance guide being used for alignment purposes? } \\
\text { Tap-hole lay- Binder trye }\end{array}$ & $\mathrm{Y} / \mathrm{N}$ & $\begin{aligned} r \\
\text { pitch }\end{aligned}$ & $\stackrel{N}{\text { water }}$ & $\mathrm{N}$ & $\mathrm{N}$ \\
\hline Tap-hole clay - Type of ageregate used (material composition) & . & alumina-based & other & aluminatebased & aluminaterased \\
\hline \multicolumn{6}{|l|}{\begin{tabular}{|l} 
TAPHOLE DESIGN \\
\end{tabular}} \\
\hline Number of bricks in tap-hole & $\bar{*}$ & 7 & $1.540 \mathrm{~mm}$ block & 5 & 5 \\
\hline Primary refractory type used & & alumina-based & alumina-based & magnesia-based & magnesia-based \\
\hline Water-cooling used & . & Water-cooled Block and Faceplate & Water-cooled Block and Faceplate & Water-cooled Block and Faceplat & Water-cooled Block and Faceplate \\
\hline Single block or multiple brick tapping channel design & $\therefore$ & multiple brick modules & single block & single block & single block \\
\hline \multirow{2}{*}{\multicolumn{6}{|c|}{\begin{tabular}{|l} 
TAP-HOLE REPAIRS \\
\end{tabular}}} \\
\hline & & & & & \\
\hline $\begin{array}{l}\text { Typical taphole life before replacement } \\
\text { Preventative maintenance- }\end{array}$ & months & 24 & 125 taps & 1 & 1 \\
\hline $\begin{array}{l}\text { Preventative maintenance - frequency of repair of a given tap-hole } \\
\text { Preventative maintenance basis }\end{array}$ & days & 14 Number of taps and tapoing time & not known yet & 30 & 30 \\
\hline Preventative maintenance basis & & & number of taps & number of taps & number of taps \\
\hline
\end{tabular}




\section{Tapping of PGM-Ni mattes: an industry survey}

Material selection in tap-hole bricks is often driven by risk management, and these trials have to be carried out judiciously due to the potential loss in production associated with selection of an unsuccessful material. Alumina may be at risk if the tap-hole is frequently washed with slag; in such cases, $\mathrm{MgO}$ or $\mathrm{MgCr}$ are generally better suited. Figure 1 indicates that $44 \%$ of all respondents use alumina-based matte tap-hole refractories, whereas 56\% use magnesiabased refractories. As seen in Figure 2, matte tapping temperature is not a criterion in refractory selection.

\section{Tap-hole operation and tapping practices}

For the purposes of this paper, tap-hole productivity is defined as the tons of matte tapped per day per tap-hole. When comparing the PGM, nickel matte, and copper matte smelting industries, three distinct regimes are observed (Figure 3).

The tap-hole productivity is lowest for PGM smelting furnaces (1590 t/d per tap-hole). The productivity per taphole is higher for the nickel matte furnaces (25-210 t/d per tap-hole), despite operating with more tap-holes (from two to six). Literature data for copper flash smelters (operating with four to six matte tap-holes) shows a step change in tap-hole productivity to $220-470 \mathrm{t} / \mathrm{d}$ per tap-hole. The productivity benchmark for PGM smelting $\left(>1350^{\circ} \mathrm{C}\right)$ is currently set by Polokwane and Waterval at $90 \mathrm{t} / \mathrm{d}$ per tap-hole (on average).

For a given matte tapping temperature, there is a large variability in tap-hole productivity. This is due to the fact that regardless of the size of the furnace, there is a minimum number of two matte tap-holes for redundancy and maintenance purposes. Hence, while the Stillwater furnace and the Waterval furnace both have two matte tap-holes, the Waterval furnace has a much higher matte production rate, resulting in higher tap-hole productivity.

With regard to tapping frequency, it is important to consider if tapping a particular furnace needs to be synchronized with a downstream converter operation. The tapping frequency at operations that are decoupled from converter operation should be driven by furnace levels, whereas furnaces feeding downstream converters (as molten feed) are typically tapped 'on demand' to suit the converter cycles (Figure 4).

At Northam in particular, matte is tapped only once per day to feed the daily converter cycle. This is the only operation tapping two ladles at a time in order to have sufficient material to feed the converter; all other furnaces tap one ladle at a time. This results in a very long time of 1380 minutes between taps for Northam.

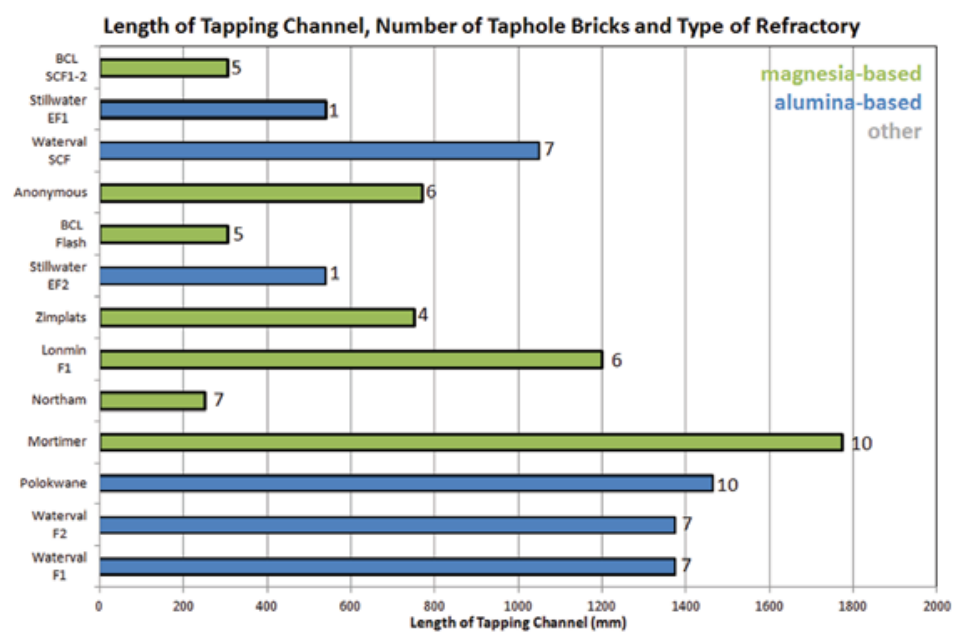

Figure 1-Length of tapping channel, number of tap-hole bricks, and type of refractory

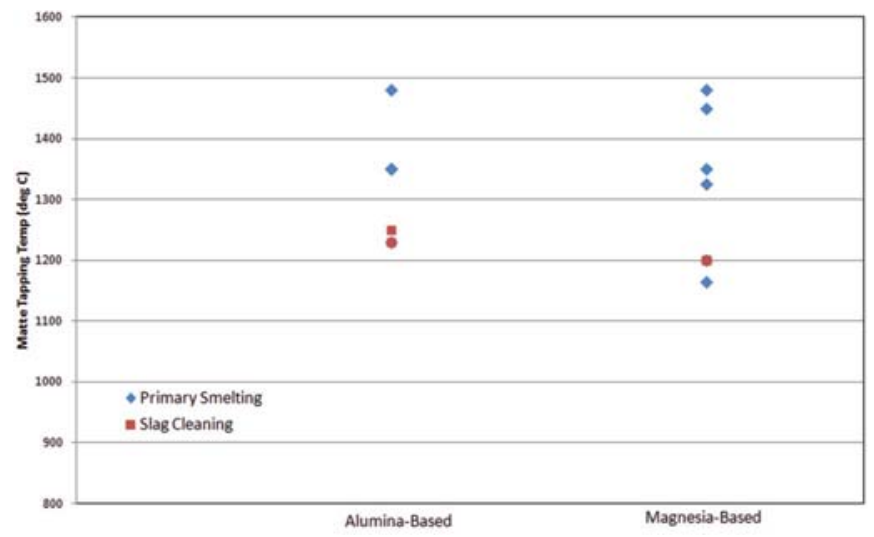




\section{Tapping of PGM-Ni mattes: an industry survey}

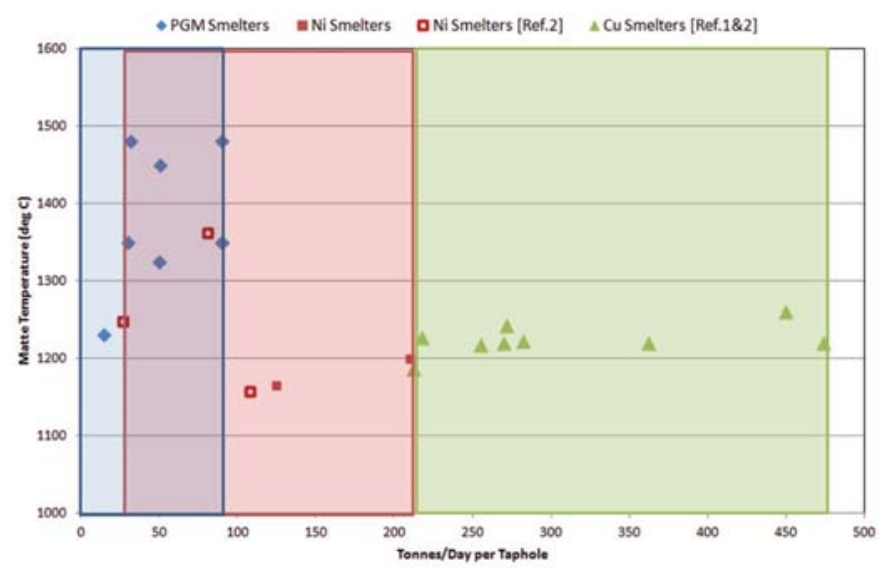

Figure 3-Matte tapping temperature vs. productivity per tap-hole. PGM and Ni smelters based on survey, selected Ni and Cu smelters based on literature data (Schlesinger et al., 2011; Davenport et al., 2003)

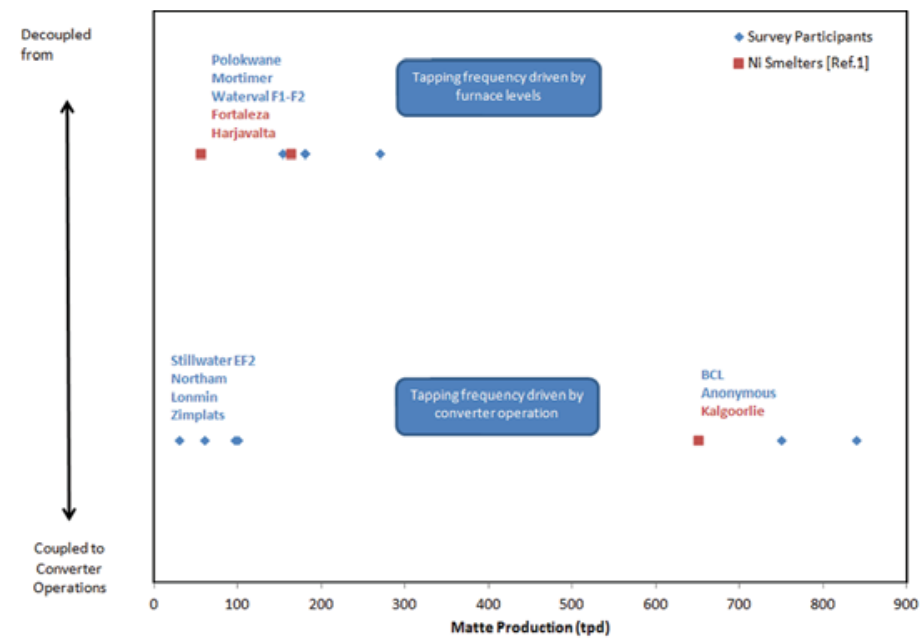

Figure 4-Level of coupling to converter operations vs. smelter matte production for survey participants and literature data (Schlesinger et al., 2011)

BCL and the anonymous smelter produce a large amount of matte (750-840 t/d) and need to regularly feed downstream converters, resulting in a time of 17-21 minutes between taps (i.e. many short taps). PGM operations produce less matte (30-270 t/d), resulting in longer times of 100 to 237 minutes between taps (excluding Northam).

The slag cleaning furnaces are different in nature and typically tap between two to six times per day ( 225 to 700 minutes between taps), except for Stillwater EF1, which taps only once a month. The time between taps can be plotted against tap-hole productivity, clearly showing three different zones for the slag cleaning furnaces (excluding Stillwater EF1), PGM smelting furnaces (excluding Northam), and Ni smelting furnaces (Figure 5).

Most furnaces have a tap duration of 10-15 minutes (Figure 6), except for Northam (60 minutes to fill two ladles) and the $68 \mathrm{MW}$ Polokwane furnace (20-35 minutes due to their larger tap size of 28-32 t). Stillwater has very short tapping times of three minutes, because of the very small tap size of $5 \mathrm{t}$.

Excluding Stillwater because of the very short tap duration, average matte tapping rates vary between 0.5 and
$1.4 \mathrm{t} / \mathrm{min}$ (Figure 6). None of the PGM smelting furnaces tap faster than $1.2 \mathrm{t} / \mathrm{min}$. The nickel smelters tap faster (between 1.2 and $1.4 \mathrm{t} / \mathrm{min}$ ), but at a lower matte temperature. Matte tapping time (obviously related to tapping rate) is an official tap-hole repair trigger criterion for five of the participating furnaces: all five participants show an average matte tapping rate of $\leq 1 \mathrm{t} / \mathrm{min}$. Stillwater, Polokwane, and Mortimer are the only PGM smelters tapping matte at rates faster than $1 \mathrm{t} / \mathrm{min}$ (on average).

The majority (66\%) of the participating primary furnaces use alternate tap-holes for consecutive taps, allowing a given tap-hole some 'resting' time before its next thermal event. The objective of this practice is to enable the tap-hole temperature to return to its baseline level before the next tap. Other smelters use the same tap-hole for consecutive taps and the tap-hole remains 'hot' between taps.

For tap-hole opening, 36\% of participating furnaces use oxygen lancing whereas the majority use a combination of drilling and lancing. Best-practice operations make use of a lance guide to minimize the potential for damaging the taphole when lancing it open. All participating smelters use mudguns for tap-hole closing, with the exception of Northam 


\section{Tapping of PGM-Ni mattes: an industry survey}

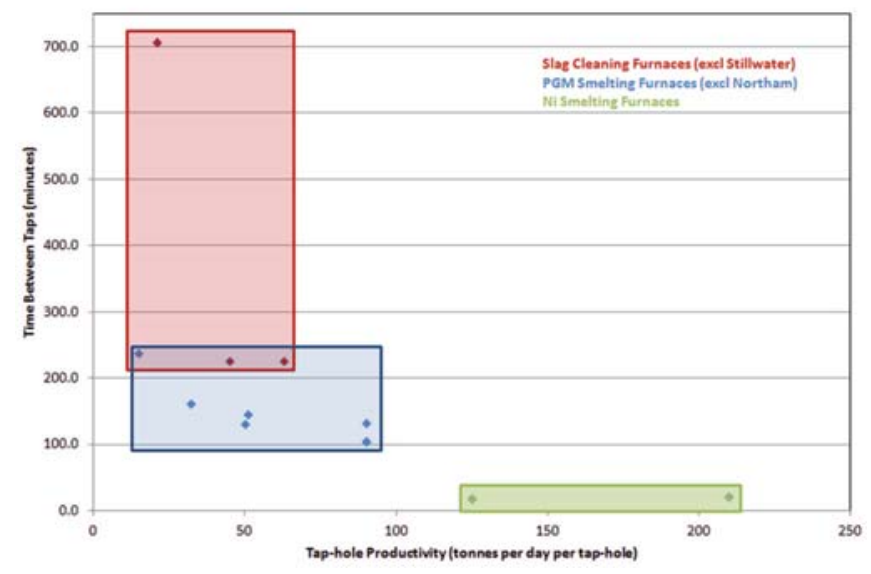

Figure 5-Time between taps vs. taphole productivity for slag cleaning furnaces, PGM smelting furnaces, and Ni smelting furnaces

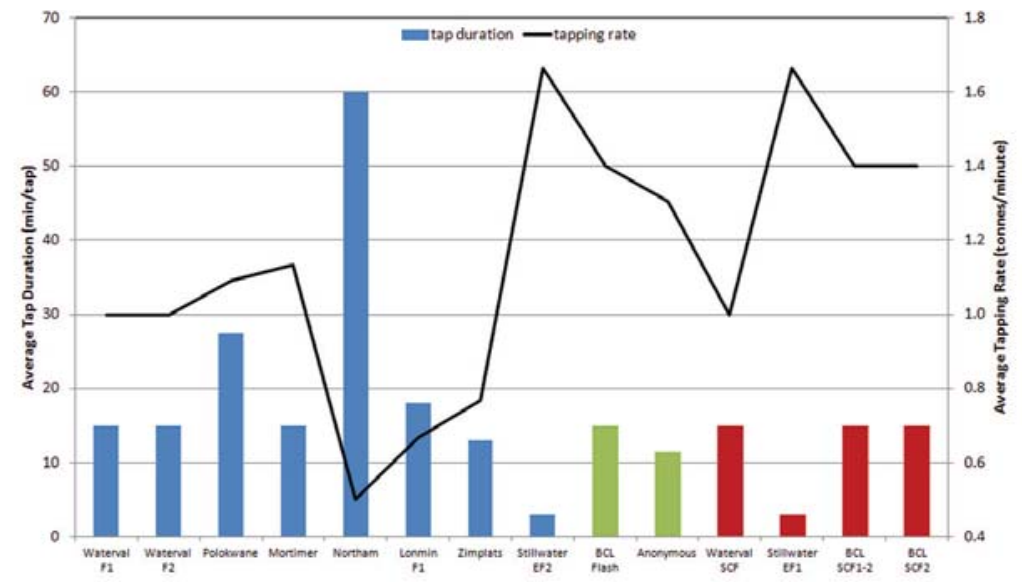

Figure 6-Average tap duration and tapping rate

and BCL (Table II). Tap-hole clay also plays a role in tap-hole life. The quantity of clay injected must be monitored to avoid excessive clay causing gas bubble-driven turbulence in front of the tap-hole hot face. Best-practice operations measure and monitor the amount of clay injected for each tap-hole closure event.

Tap-hole clay technology constantly evolves with new aggregates, binders, and additives. For example, in the blast furnace industry, additives such as $\mathrm{SiC}, \mathrm{SiN}$, and zirconium are used to modify the flowing/hardening behaviour of the tap-hole clay. Water-based clays are no longer used in the blast furnace industry as they contribute to the oxidation of the carbon-based tap-hole refractories. Tar-bonded clays are still widely used but raise health concerns due to the carcinogenicity of their volatile component. Phenolic resins and pitch/resin mixtures can also be used as binders. In PGM and nickel matte smelting, water-based clays and pitchbonded clays are widely used (Figure 7). Resin-bonded clay is used at only one smelter (anonymous), which also reports using graphite components in their taphole. Most furnaces (79\%) use alumina-based aggregates. One smelter (Northam Platinum) uses locally sourced soil, and one other smelter (two furnaces) uses an unspecified tap-hole clay aggregate (Figure 7).

\section{Tap-hole maintenance}

The tap-hole repair cycle affects furnace availability and utilization (productivity). The downtime associated with taphole repairs depends on many factors: the number of tapholes that are simultaneously repaired, the number of bricks replaced, the ramp-down and ramp-up schedules, operating load during a repair (reduced load, no load), etc.

Most smelters repair only one tap-hole at a time. This could lead to an increased overall downtime for the furnace if the repairs are not scheduled optimally, depending on the duration and ramp-up/down schedule surrounding the repair. In some cases, the loss in production associated with the ramp-up/down can be as, if not more, important than the duration of the repair itself. Some smelters make use of nitrogen or plant air to cool the tap-hole during a rebuild.

It is standard practice to carry out both partial tap-hole repairs, in which only a certain number of bricks from the tapping channel are changed, and deep repairs. In some cases, deep repairs are done with furnace power on (idling power).

Each smelter has developed its own set of criteria to trigger tap-hole repairs. Some smelters use the number of taps, others the tapping time, and some a combination of 


\section{Tapping of PGM-Ni mattes: an industry survey}
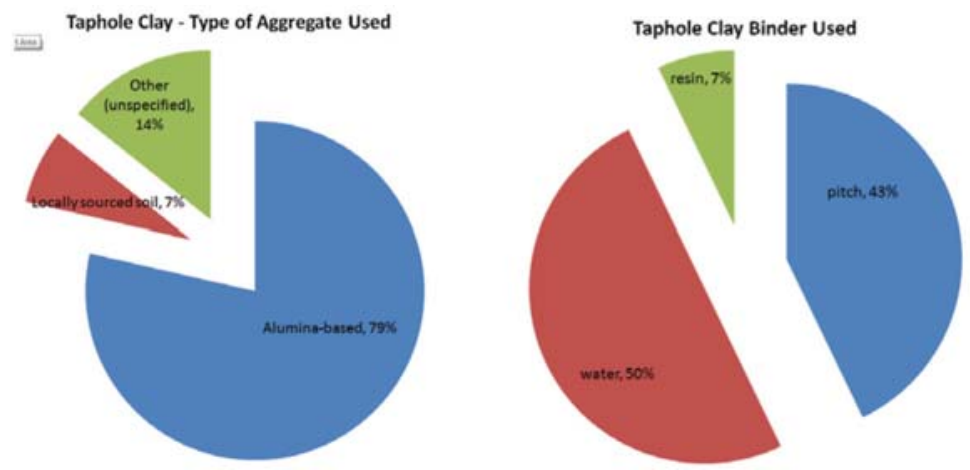

Figure 7-Tap-hole clay - type of aggregate and binder used

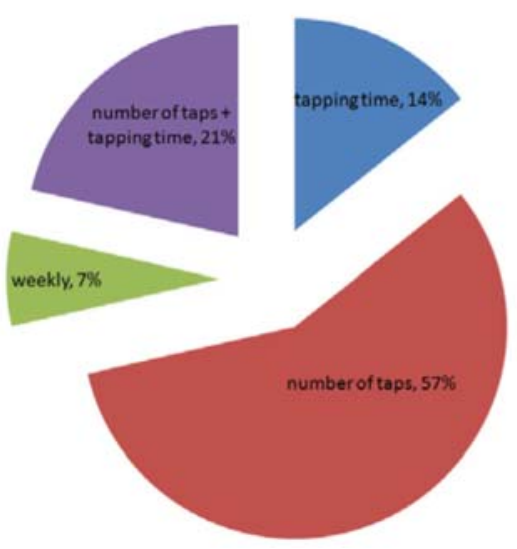

Figure 8-Primary tap-hole repair trigger criteria

these parameters. One smelter simply repairs the tap-holes on a weekly basis, regardless of production indexes (Figure 8). In addition, some smelters also evaluate other factors such as copper temperatures and observations of inner brick condition during partial repairs as secondary repair trigger criteria.

It is difficult to compare tap-hole campaign life reported in the survey because the basis varies from one smelter to another. For example, some smelters reported life of the entire tap-hole, whereas others reported life before a partial repair.

\section{Conclusions}

A survey of this nature provides the means to compare matte tapping practices across operations and across industries. It can provide stimulus for operators to challenge their own criteria for maximizing the life of the tap-hole refractories before a repair is triggered. Beyond having an understanding of current practice in the industry, it is critical to have a good knowledge of one's own tapping practices. Records should be maintained of the following:

> Brick types and specifications, and when they were installed and removed from the tap-hole

> Tap-hole clay type

> Tap-hole opening/closing events for each tap-hole, including time open, time closed, duration, tons tapped (and derived tapping rate), etc.

> Matte tapping temperatures and matte compositions for each tap
> Photographic records of each tap-hole repair, including a photograph of each brick before it is broken out and as it is re-installed.

The intent is to keep updating this matte tapping database and to obtain more participants across a wider range of matte smelting industries. Anyone wishing to participate in this effort is invited to contact the author at inolet@hatch.co.za.

\section{Acknowledgements}

All participants to this survey are gratefully acknowledged. Special thanks to Johan Nell (Hatch), Lloyd Nelson (Anglo American), and Terrence Koehler (Hatch) for their input into the questionnaire.

\section{References}

Davenport, W.G., Jones, D.M., King, M.J., and Partelpoeg, E.H. 2003. Flash Smelting: Analysis, Control and Optimization. 2nd edn. TMS Publications, Warrendale, PA.

Schlesinger, M.E., King, M.J., Sole, K.C., and DAvenPoRT, W.G. 2011.Extractive Metallurgy of Copper. 5th edn. Elsevier, Amsterdam.

Shaw, A., De Villiers, L.P vS., Hundermark, R.J., Ndlovu, J., Nelson, L.R., Pieterse, B., Sullivan, R., Voermann, N., Walker, C., Stober, F., and McKenzIE, A.D. 2012. Challenges and solutions in PGM furnace operation: high matte temperature and copper cooler corrosion. 5th International Platinum Conference: 'A Catalyst for Change', Sun City, South Africa, 18-20 September 2012. Southern African Institute of Mining and Metallurgy, Johannesburg. pp. 193-216. 